
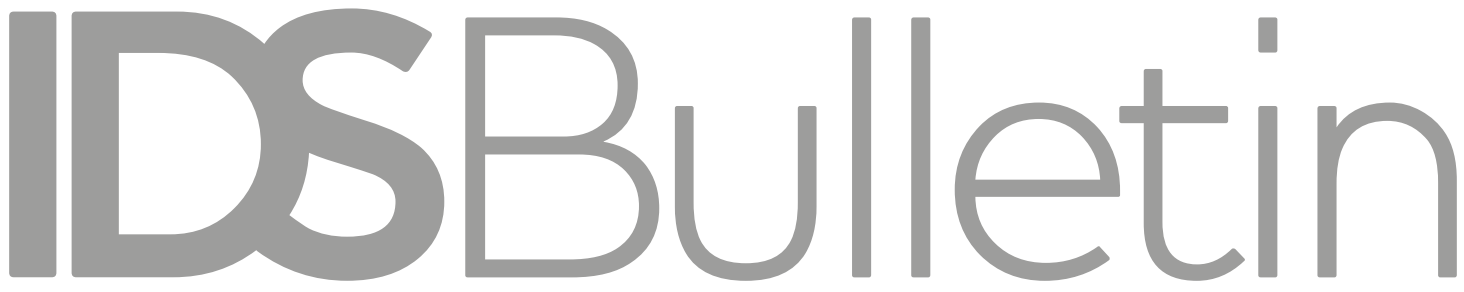

Transforming Development Knouledge

Volume 49 | Number 5 | November 2018

\title{
YOUTH EMPLOYMENT AND THE \\ PRIVATE SECTOR IN AFRICA
}

Editors Seife Ayele, Dominic Glover and Marjoke Oosterom

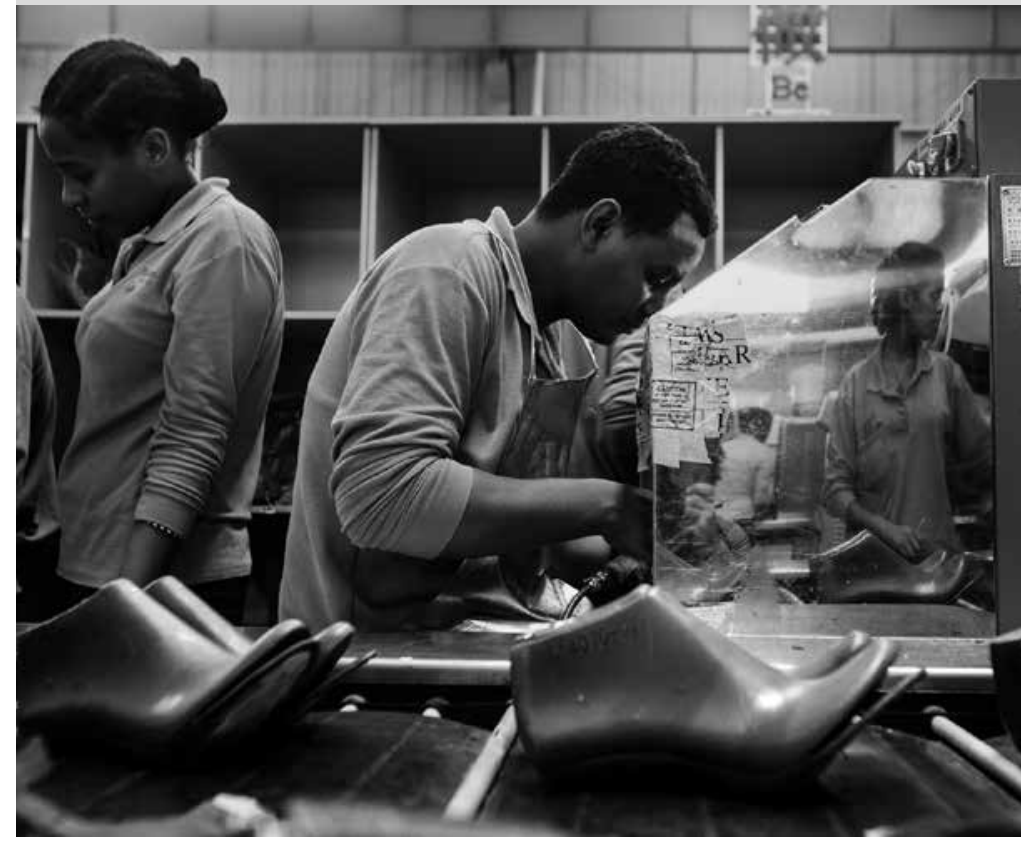


Notes on Contributors

Clementina Oluwafunke Ajayi In Memoriam

Introduction: Youth Employment and the Private Sector in Africa

Seife Ayele, Marjoke Oosterom and Dominic Glover

Ethiopia's Agricultural Transformation: Agribusiness' Contribution to Reducing Youth Unemployment

Tesfamicheal Wossen and Seife Ayele

Labour Casualisation and Youth Employment in Ghana's Formal Private Sector Gertrude Dzifa Torvikey

Uganda's National Youth Policy and Job Creation for Youth Rita Makumbi

Skills Gaps and Mismatches: Private Sector Expectations of Engineering Graduates in Ethiopia

Jerusalem Yibeltal Yizengaw

Fostering Agribusiness Entrepreneurship for Kenyan Youth through Practice-Based Education

John Muchira

Navigating Precarious Livelihoods: Youth in the SME Sector in Zimbabwe

Simbarashe Gukurume

Assessing the Effectiveness of Employment Programmes for Ex-Combatants:

A Case Study of Nigeria's Post Amnesty Programme (PAP)

Tarila Marclint Ebiede

Clossary 


\title{
Skills Gaps and Mismatches: Private Sector Expectations of Engineering Graduates in Ethiopia'
}

\author{
Jerusalem Yibeltal Yizengaw ${ }^{1}$
}

\begin{abstract}
This article investigates skills gaps and mismatches of engineering graduates. Sustained growth of the Ethiopian economy has created demand for construction work, yet despite the labour demand and engineering graduates seeking employment, employers identify skills gaps hindering their ability to employ them. The study uses key informant interviews with engineering graduates, lecturers, and private sector employers, and document analysis to collect data on the skills gaps and mismatches. The article argues that, while skills gaps are largely caused by poor design of the higher education curriculum and corrupted recruitment practices, the precarious nature of the construction sector and macroeconomic instability limit graduate employment even further. It suggests that education providers work collaboratively with employers to make the curriculum fit for purpose, and that government both makes more realistic and long-term plans for the construction sector, and increases university funding, with an emphasis on quality and practice-focused graduate teaching and learning experiences.
\end{abstract}

Keywords: private sector, construction, youth, graduates, engineering, skills gap, higher education curriculum, (un)employment.

\section{Introduction}

In recent years, Ethiopia has registered a remarkable economic performance, with annual growth of gross domestic product (GDP) averaging 10.3 per cent per year from 2005 to 2015 . Ethiopia aspires to become a middle-income country by 2025 (FDRE 2016) and also aims to sustain its current economic growth through its second Growth and Transformation Plan (GTP II) (ibid.). A key component of the GTP II is the construction sector, which is at the heart of enhancing national competitiveness and creating employment opportunities. During the GTP I period (2010/11-2014/15), the construction industry grew at an average of 28.7 per cent per annum, increasing its share of GDP from 4 per cent in 2009/10 to 8.5 per cent by 2014/15 (ibid.). The sector also employs 11 per cent of the total formal sector employment (CSA 2014). 
Given its labour-intensive nature, employment in the construction sector is expected to grow. This is reflected in the ambitious GTP II targets for the sector; for example, total road length is planned to increase from $110,414 \mathrm{~km}$ in $2014 / 15$ to $220,000 \mathrm{~km}$ by $2019 / 20$, and a total of $2,741 \mathrm{~km}$ of national railway network is expected to be constructed by 2019/20 (FDRE 2016). Although most of the GTP plan is state-led and state-financed, a significant portion of this work is expected to be delivered by the private construction sector through contracts (ibid.). The sector, however, suffers from a low level of capacity and skills, weak performance of contractors and consultants, high costs of construction materials, and the prevalence of rent-seeking behaviours (FDRE 2016; EEA 2008).

This article focuses on skills gaps and mismatches. This is an area that the Government of Ethiopia has also been focusing on through expanding higher education which emphasises science, technology, engineering, and mathematics (STEM) against the broader areas of social sciences (a 70:30 split in favour of STEM). The number of universities in Ethiopia increased rapidly from two in the 1990s to 44 in 2016, and total enrolment on undergraduate degree programmes grew from 420,387 in 2009 to 778,766 in 2016 (FDRE/Ministry of Education 2017). However, the quality of higher education in creating competitive graduates has been highlighted as a major problem (Salmi, Sursock and Olefir 2017); and the general root of the problem stems from the expansion and dynamism of the Ethiopian higher education system.

While the number of graduates has been growing, evidence from a 2013 survey showed that the unemployed working-age population in Ethiopia was 1,981,165, with an unemployment rate of 4.5 per cent (CSA 2014). The differentials of unemployment by gender showed that the female unemployment rate (6.5 per cent) was more than double as compared to their male counterparts (2.7 per cent) (ibid.). Youth unemployment is as high as 20 per cent (Wossen and Ayele, this IDS Bulletin), with unemployment particularly concentrated among the 15-29 years age group. This is the age range which the Ethiopian youth policy regards as 'youth' (FDRE 2004), even though non-governmental organisations (NGOs) and civic associations in Ethiopia and other countries use various ranges for the concept of 'youth' from the standpoint of the purpose which they represent and activities they undertake. For example, the United Nations (UN) defines youth as persons between 15 and 24 years and the World Health Organization (WHO) defines it as 10-24 (FDRE 2004). Again, experiences of other countries indicate different age ranges to define youth (see e.g. Ayele, Khan and Sumberg 2017).

Ethiopia has one of the highest rates of graduate youth unemployment in East Africa (Addis Standard 2017). For example, a 2015 tracer study of Bahir Dar University (BDU) shows that out of the 1,301 young engineers included in the study, 35.4 per cent were unemployed (BDU forthcoming, 2018). While data on graduate (un)employment are anecdotal, some studies (e.g. Mncayi 2016 and Salmi et al. 2017) suggest that graduate engineers are among the growing number of unemployed 
youth. The adverse consequences of youth unemployment on families and society at large is evident; for example, partly triggered by the youth unemployment crisis, Ethiopia has recently experienced major political unrest, which led the government to impose two states of emergencies (Addis Standard 2017; BBC 2018). Though the initial spark for these unrests was potential land-grabbing, one of the causes admitted by the government was youth unemployment (Africa Renewal 2017). Besides, regional inequalities in infrastructure provision, poor performance of flagship projects (such as hospitals), unlawful displacement of farmers, lack of rule of law, absence of civil society fora, and lack of vibrant media have all contributed to the flaring up of public disappointment and hence the unrest (Addis Standard 2017). The government also took what appears to be a knee-jerk solution to curb the unrest and allocated 10 billion birr (around US $\$ 400$ million) to create job opportunities, particularly for young people (ibid.).

Researchers such as Gebremariam (2017) and Gebru (2017) call for overhauling the economy and creating better employment opportunities for unemployed youths and graduates in the country. Otherwise, if the problem is left to chance, a mismatch between education and employer expectations in Ethiopia could have serious long-term repercussions - particularly because Ethiopia is the second most populous African nation, with over 70 per cent of its population under the age of 30, and with over 150,000 graduates each year (Africa Renewal 2013; Korpela 2017). In light of the key role youth are expected to play in the sustained political and economic stability of the country, and the importance of taking a closer look at the plight of the youth and possible solutions to the chronic problem of youth unemployment, there are complaints heard from employers in Ethiopia that their expectations are not met in finding proper graduates of tertiary-level education who are both competent in theoretical knowledge and also able to practise it efficiently (Salmi et al. 2017). Under these circumstances, it is therefore imperative to explore the causes of skills gaps and mismatches among graduate engineers and identify possible solutions with a view to enhancing employment in the sector as well as economic development of the country.

The remainder of the article is organised as follows. Section 2 reviews the literature on the status of youth (un)employment and the private construction sector. Section 3 outlines the methods used in the study, while Section 4 presents and discusses the findings. Section 5 concludes and provides policy recommendations.

\section{The status of youth (un)employment and the private construction sector in Ethiopia}

Research shows that Africa's youth population is rapidly growing and is projected to double to over 830 million by 2050 (AfDB 2016). Demographic projections also show that 1 billion more young people will enter the job market over the next decade (Kilimani 2017). This demands for state and non-state actors to expand the social and economic sectors and provide employment opportunities progressively 
for youth (Gebremariam 2017). In developed countries such as the USA and Japan, private firms invest more proportionally and are more responsive to change in investment opportunities than are public firms (UNCTAD 2017). But in developing countries like Ethiopia, public sector investment is dominant while the relative role of private investment in economic growth is in its infancy (Melese 2012). Yet the Ethiopian construction industry has contributed much to reducing poverty (FDRE 2016), for instance through increasing employment expansion through small- and medium-enterprise development and job creation through the construction of low-cost houses (Tefera 2013). Despite the key roles that the private sector can play to drive economic growth and thus eradicate poverty (World Bank 2018), the degree of youth absorption in Ethiopia through employment is found to be low (Yizengaw 2016).

The notions of 'youth bulge' and 'demographic dividend' have also become key aspects of the narrative around youth and employment policy (Ayele et al. 2017). While 'youth bulge' refers to the situation where a large share of the population comprises children and young adults, the notion of 'demographic dividend' is built around the potential that the youth can generate social and economic growth (ibid.). Alongside these narratives are also concerns about the 'risky behaviours' among unemployed and underemployed youth who are often exposed to unprotected sex, abuse of alcohol and drugs (ibid.), and political and social instability (Gebremariam 2017).

Ethiopia prides itself on achieving double-digit economic growth over the past decade (FDRE 2016). However, this growth has not sufficiently addressed the unemployment challenge. While unemployment dropped from 20.4 per cent in 2010 to 16.8 per cent in 2016, it still remains significant and youth unemployment is even more pronounced (Wossen and Ayele, this IDS Bulletin; World Bank 2018). The construction industry is labour-intensive and has grown over 20 per cent in the past decade, even faster than the overall growth of the economy (FDRE 2016). Due to the fact that it provides jobs, especially for less-skilled labourers, the sector's contribution to poverty reduction has been noted (Tefera 2013). What is more, given the booming construction works across the country, the sector also visibly provides employment opportunities for engineering graduates (CSA 2013). However, as noted above, studies show that over 35 per cent of the 2015 engineering graduates were unemployed (BDU forthcoming, 2018).

The broader literature suggests that volatile economic growth accompanied by a poorly educated workforce and skills shortages risks the employability of graduates (World Economic Forum 2014). Further, Aring (2012: 5) underlined that skills gaps are caused by two major factors: (1) a qualitative skills mismatch where employers do not find graduates with employable skills even when they have the right qualifications on paper, and (2) a quantitative mismatch where not enough graduates are educated and trained at the required levels, 
or they out-migrate to countries where they can earn higher wages. According to McGuinness, Pouliakas and Redmond (2017), skills mismatches are caused by three factors:

1 Macroeconomic skills mismatch: differences between the jobs on offer and the broad qualification levels of the pool of unemployed people;

2 Specific skills shortages: employers' inability to find workers with a specific skill or occupation; and

3 On-the-job skills mismatch: differences between employed individuals' skills and the skills needed to perform their job.

McGuinness et al. (2017) further refer to 'vertical mismatch' - measured in terms of over-education, under-education, or over-skilling and under-skilling - and skills gaps - measured in terms of unfilled and hard-to-fill vacancies. Based on the above theoretical background, this article thus discusses the causes of skills gaps and mismatches.

\section{Research methodology}

This study employed a qualitative research approach. It used document analysis and in-depth interviews to generate data on the presence of skills gaps and mismatches and the reasons thereof. In total, the study draws on 38 interviews conducted over May-June 2018 with:

Sixteen university lecturers working at Addis Ababa and Bahir Dar universities, both of which are pioneers of producing engineering graduates in Ethiopia. Based on UNESCO's (2012) rating scale, lecturers' assessments of graduate employability were rated as high $=3$, medium $=2$, and low $=1$. The lecturers were quizzed on the presence of employable skills among engineering graduates.

Twelve owners and/or managers of eight small to large enterprises in the construction sector (drawn from Addis Ababa and Bahir Dar). They responded to questions concerning the private sector expectations of engineering graduates alongside the presence of skills gaps and mismatches.

Ten engineering graduates who were employed in paving roads and streets and undertaking major construction work such as upgrading inner roads, roadsides, and walkways. They were asked questions regarding the causes of skills gaps and mismatches.

Finally, the author's doctoral study (Yizengaw 2016) was also used as a secondary source of data.

\section{Data analysis and findings}

4.1 Skills gaps and mismatches among engineering graduates

Sixteen lecturers from Addis Ababa and Bahir Dar universities were asked to rate the presence of employable skills among their engineering students, ranked from high to low (see Table 1). 
Table 1 Presence of employable skills among engineering graduates in Addis Ababa and Bahir Dar universities, as perceived by their lecturers, 2016/17 academic year

\begin{tabular}{|c|c|c|c|}
\hline \multirow{2}{*}{ Employable skills } & \multicolumn{3}{|c|}{ Frequency and percentages of responses } \\
\hline & High & Medium & Low \\
\hline Subject-specific technical ability & & $6(37 \%)$ & $10(63 \%)$ \\
\hline Ability to use new information & $4(25 \%)$ & $8(50 \%)$ & $4(25 \%)$ \\
\hline Prior exposure to the work & & & $16(100 \%)$ \\
\hline Understanding business realities & & $7(43.7 \%)$ & $9(56.3 \%)$ \\
\hline Ability to construct logical arguments & & $11(68.7 \%)$ & $5(31.3 \%)$ \\
\hline Ability to execute tasks independently & & $4(25 \%)$ & $12(75 \%)$ \\
\hline Problem-solving skills & & $6(33.3 \%)$ & $10(66.6 \%)$ \\
\hline Ability to apply knowledge to new situations & $2(12.5 \%)$ & $3(18.7 \%)$ & $11(68.7 \%)$ \\
\hline Flexibility in accepting new things & & $7(43.7 \%)$ & $9(56.3 \%)$ \\
\hline Negotiation skills & & $3(18.7 \%)$ & $13(81.2 \%)$ \\
\hline
\end{tabular}

Table 1 clearly shows that except for one highly rated skills area (the ability to use new information), the graduates' skills were rated as medium or low, with subject-specific technical skills particularly rated as either low (63 per cent) or medium (37 per cent). Graduates were poorly rated in terms of their abilities to apply knowledge to new situations, having prior exposure to engineering work, and understanding business realities. Graduates' abilities to execute tasks independently and their problem-solving skills were also rated as low. It is also important to note that, although the technical demands of a graduate may vary, an engineer, irrespective of their specialisation, must be equipped with soft engineering skills such as negotiation in order to cope with new challenges in the changing engineering field. However, the graduates were rated poorly even in these soft skill areas.

Moreover, interviews with the lecturers clearly revealed that their students had much better theoretical than practical knowledge, which meant that students were barely equipped with practical and employable skills on graduation. Therefore, at least from the perspective of university lecturers, the skills levels among engineering graduates at both Addis Ababa and Bahir Dar universities were either low or medium at best.

In-depth interviews with owners and managers of private construction businesses showed that many of the graduates who they employed (or came to them in search of employment) hardly had the skills to handle budget preparation, contract and subcontract management, material requirement plans, or even warehouse management. Many also 
explained that fresh graduates required job-related specific courses and trainings before starting work because the level of skills gained at university did not meet their expectations. One of the construction companies' general managers ${ }^{2}$ noted that the graduates in question were of 'high profile on papers [sic] but not in reality'. Another reiterated that 'some of the newly recruited engineering graduates were unfit to perform simple engineering works that we expected graduates to do... we had to train them from one to six months to get them [to] make a good start'. ${ }^{3}$ These responses confirm the lecturers' responses and indicate that higher education teaching did not respond appropriately to the employers' expectations and requirements. On paper, some of these graduates were 'over-qualified' and 'entitled' to demand relatively higher wages than less-skilled labourers, but they did not do the jobs any better. In this regard, one of the interviewed private company owners explained that 'graduates even with grade points 3.5 and above are not found much better as we expected'. ${ }^{4}$ Others highlighted that such graduates add a cost to their businesses because they have to retrain them and this affects the performance of their businesses, including producing sub-standard products.

I also asked engineering graduates about their employable skill sets. A graduate of BDU explained the skills mismatch he experienced working as a bricklayer in a small business:

Our work specification includes earth work, sub-base construction, drainage ditch openings, shade building, etc. What we [fellow graduates and I] studied and what we are doing are different. There are also others [engineering graduates] who perform totally different jobs than they were trained in, like salesmen and saleswomen, hotel receptionists, [and] stores-keepers. Some others are inactive. ${ }^{5}$

Those engineers who were bricklayers (working on cobblestone projects $)^{6}$ in and around Bahir Dar claimed that they possess 'more and completely different skills than their current job requires', and that the deployment of engineering graduates to manual work reveals 'a skills mismatch' where an overly educated graduate does 'basic and manual work'. Almost the entire engineering graduates interviewed stated that the jobs they were working on could easily be conducted by trainees or graduates of Technical Vocational Education and Training (TVET). This, therefore, raises the question as to why the government focuses so much on expanding university education that is not addressing quality, and I argue that the quality of higher education has to be looked into as an urgent policy matter.

\subsection{Causes of skills gaps and mismatches}

The findings in the previous section clearly suggest some causal factors for skills gaps and mismatches. These include:

Limitations of the higher education curriculum: When it comes to the specific engineering curriculum, its relevance to the world of work is of paramount importance because, as argued by Thi Tuyet 
Tran (2014), engineers are involved in the implementation, application, operation, design, development, and management of projects and processes. This is despite the fact that the type of work that engineers do will vary depending on the chosen field of study such as chemical, civil, electrical, materials, mechanical, or industrial engineering. Regarding the relevance of the curriculum, an owner of a small firm and former graduate of BDU remarked,

I looked and looked for jobs relevant to my training for years but I [was] unable to find it. Even to create my own, the way how I was trained is not supportive to think far beyond job searching in public institutions. As a last resort, I organised myself with friends and started working on small-scale inner roads maintenance work, initially for subsistence reasons but now it is more rewarding. ${ }^{7}$

Another former graduate of Addis Ababa University stated strongly how government officials insist that engineering graduates are involved in jobs such as cobblestone projects. This, according to the interviewee, 'undermines the five-year-long preparations at the university and wastes the knowledge and skills obtained at the university'. So far, the interviewee is of the opinion that 'the concerns of these higher officials may be useful if it urges universities to revisit their curriculum according to the demands of employers'. ${ }^{8}$ As curriculum and pedagogics matter most of one's entire career, higher education needs to be responsive in its curriculum and methodologies with the promise of teachers in embedding and teaching entrepreneurship courses to their students. While some of the former graduates insisted that they have the right skills, some of the employers do not find them relevant and blame the poorly designed curriculum and a lack of resources to prepare graduates for work after graduation. The perceptions held by employers and university lecturers and their evaluations of the graduates' skills are that these are largely based on principles and theories. This clearly suggests that the curriculum is poorly designed and does not address the expectations of employers.

Precarious nature of the construction sector: A large part of the construction industry boom in Ethiopia is due to state-led and state-financed construction projects such as dams, roads, and railways. However, the sector is vulnerable to contract delays and underfinancing, and even cancellations of major projects. Under these circumstances, according to one of the interviewed graduates, 'private contractors struggle to hire and retain graduates'. ${ }^{9}$ As another employer noted, the difficulties in hiring and retaining graduates are even more 'accentuated by the inability or lack of willingness of some graduates to take multiple positions (or multitasking) ${ }^{\prime} \cdot{ }^{10}$ Yet another employer noted that, given 'we have to make profits and survive; we expect our staff to take two or more simple tasks that are in the domain of the construction industry'. ${ }^{11}$ The view of the interviewee was that enterprises are able to create more spaces for graduates in different positions so long as the latter are willing to take them. 
Lack of quality higher education: One of the interviewed lecturers expressed 'to think about quality graduates we need to have adequate resources in higher education institutions. In the reality, there are limitations in resources to increase quality in university educations $[s i c]$ '. ${ }^{12}$ The engineering graduates also highlighted insufficiency of funding while they were on campus or studying. They noted that their lecture theatres and workshops were poorly equipped; for example, insufficient tools and equipment to undertake practical learning. They also explained that their libraries did not hold relevant and sufficient books. Some even went on to say that their teaching staff were not properly trained. These, I argue, are plausible reasons that undermine quality learning at the universities.

Corrupted recruitment practices: All of the graduate interviewees noted the challenges associated with securing jobs immediately after graduation due to lack of opportunities in both the private and public sectors. They also noted that the longer they remain out of jobs, the more likely they are to become deskilled which further reduces their chances of being employed. While this has been a challenge, graduates noted what they regarded as unacceptable recruitment practices in both the private and public sectors, such as 'starting to fill vacancies from the family circle by those private construction enterprises ${ }^{13}$ but not advertising openly, and procedures that are corrupt and lack transparency. Specifically, one of the interviewed graduates remarked that 'employers should be fair and give equal chances for all job applicants while recruiting alongside supporting continued growth of their staff by educating them and providing the necessary rewards in terms of pay, benefits, and work environment'. ${ }^{14}$

Factors related to the macroeconomic condition: Employers noted that their business operations often experience shortages of foreign exchange and raw materials, with one business owner stating that, 'due to foreign exchange shortages, we were not able to import key construction materials... and this affects our operations and the number of staff we hire and retain'. ${ }^{15}$ On the other hand, one of the interviewed private construction company managers explained that,

the macroeconomic environment tends to fail to use engineering graduates in productive sectors as immediately as possible. As a result, those minds and hands shaped to contribute a lot for the national and international socioeconomic dynamics remain to be idle for some time with the adverse effects of expired knowledge and skills. ${ }^{16}$

In relation to this, another interviewed private construction business owner added,

the macroeconomic situation of the country was characterised by shortage of hard currencies. Consequently, the inputs for the running projects are inconsistent and the numbers of construction projects appear to shrink from time to time which in turn affects the employment of youth graduates. ${ }^{17}$ 
To add to this reflection, the goal of achieving full employment among other macroeconomic goals is an important one in many developing nations where unemployment and underemployment have been a major cause and consequence of widespread poverty (Sodipe and Ogunrinola 2011). Above all, this research uncovered several strategies that employers used to address skills gaps, including:

Outsourcing: Some employers outsourced a significant part of their work, partly due to a shortage of skilled staff. One of the companies I visited, for example, subcontracted no less than 15 per cent of its operations to another contractor. As it happened, the subcontractors were either graduates of TVET centres or universities. Employers did believe that they were contributing to graduate employment generation directly or indirectly, through subcontracting as well as through involving graduates with quite a range of activities, including building shades and fences, and making bricks.

Skills imports: Employers and graduates alike commented on the practice of 'skills imports', particularly by foreign-owned companies. These companies bring qualified staff from abroad and hire a semi-skilled or unskilled domestic workforce. This was reiterated by one of the general managers of a foreign-owned company, who said 'our company hired engineers from abroad not from the domestic ones'. ${ }^{18}$ This provides a clue that there are situations where foreign direct investment may not contribute to the absorption of youths who are graduates but yet unemployed, unless there are mechanisms to urge them to leave some positions for local youths. Otherwise, the probability of transferring knowledge and skills of engineers from developed or developing countries to the underdeveloped ones will remain a longterm vision. This may likely be due to their having less regard for the available skills among graduates. I argue that this practice, particularly if widespread, limits the possibilities for skills transfers as graduates do not work directly with expatriate staff.

Short-term training: Employers I interviewed noted that they routinely provide short-term training for new employees, particularly graduates. Often the training they offer helps graduates adjust to the working conditions in their respective companies, but this comes at a cost - both financially and also because there is no guarantee of making the new recruit commit to the company.

Coaching: I have noted many instances of skills mismatches where graduates are placed in positions that have nothing to do with their university training. I have also come across cases where senior staff coach new staff, particularly those deployed in areas that they were not trained in. Some of the employers noted that this practice saved them time and resources that would have been spent on organising formal training for new staff. 


\section{Discussion and conclusions}

This study explored private construction sector employers' expectations of engineering graduates, focusing on how these expectations are not being met due to skills gaps and mismatches, and the reasons for this. I also explored the strategies companies used to bridge skills gaps.

I found that, while employers in the private (as well as public) construction sector expect to employ well-equipped and adaptable engineering graduates, universities produce graduates mainly equipped with theoretical knowledge but short in practical skills. Skills gaps manifest in technical skill areas as well as communication and teamwork skills, problem-solving skills, and so forth. On the other hand, widespread deployment of graduates to manual works such as bricklaying clearly shows the presence of skills mismatches, which undermines years of university-level training. In a nutshell, expectations of private construction sector employers are found to be unmet, and the root cause of the problem points to weakness of the university engineering curriculum which, it appears, has not been designed to address the needs of employers. It should also be noted that the observed new ways of working and more frequent changes in the world of jobs (by necessity or opportunity) call for a broader set of skills.

Therefore, the higher education curriculum needs to be responsive to the interests of employers and take planned action to equip graduates with the required and up-to-date employability skills. For the most part, efforts for the development of employability skills and attributes should be integrated within the curriculum. The fact that teaching and learning at the universities has been inadequately funded has also contributed to a low level in quality of graduates. In response to this, emphasising and recognising the importance of teaching quality, it is important to encourage teachers to devote time and effort in modern methods of teaching (Salmi et al. 2017). In relation, the most recommendable approach to support and reward teaching excellence is the use of targeted funding; this is successfully used in a number of developing and developed countries (ibid.). Moreover, private contraction work is dependent on government contracts and the availability of foreign exchange to import contraction materials. More often, contracts to the private sector were either delayed or underfinanced. These, coupled with shortages of foreign exchange and raw materials, have limited the sector's ability to hire and retain graduates.

Moreover, recruitment practices, particularly within the private sector, lack transparency and equal employment opportunities. In this regard, it is not uncommon to see many graduates being hired through friends and family circles, worsening the unemployment conditions for many talented graduates who lack such (it has to be said, unethical) connections. Consequently, employers should abide by the merit-based code of conduct upon recruitment of graduates. 
The strategies employers reported to use to overcome challenges of skills gaps and skills mismatches, are: outsourcing, skills imports, short-term training, and substituting or co-coaching. Nonetheless, the study highlighted the need to improve the quality of graduate-level education in universities. While the expansion in higher education and in the engineering sector in particular is commendable, this has to be matched by high graduate standards. Quality has to be a number one priority, and students need to be taught practical and entrepreneurial courses. In other words, more emphasis should be placed in the higher education institutions to bridge skills gaps and mismatches of the graduates and to produce competitive and compatible graduates who can meet private sector expectations.

Encouragement of engineering graduates to seek out jobs by setting up their own businesses and providing the necessary support should not be left to chance, but is the concern of policymakers, universities, and all other stakeholders. I recommend that the Ministry of Education, universities and faculties, and employers (both private and public sector) work collaboratively to create more spaces for graduates and also serve society. Further, educators, political leaders, and the media have to devote time, resources, and attention towards private sector growth to enhance chances for youth employment opportunities.

\section{Notes}

* This issue of the IDS Bulletin was produced in partnership with Mastercard Foundation.

1 Bahir Dar University, Ethiopia.

2 Personal interview, May 2018.

3 Personal interview, May 2018.

4 Personal interview, May 2018.

5 Personal interview, June 2018.

6 The youth often organise themselves in micro and small enterprises and undertake minor town and city roads, pavements, etc.

7 Personal interview, May 2018.

8 Personal interview, May 2018.

9 Personal interview, May 2018.

10 Personal interview, June 2018.

11 Personal interview, May 2018.

12 Personal interview, June 2018.

13 Personal interview, May 2018.

14 Personal interview, May 2018.

15 Personal interview, May 2018.

16 Personal interview, June 2018.

17 Personal interview, June 2018.

18 Personal interview, June 2018. 


\section{References}

Addis Standard (2017) 'Commentary: Protest-Driven "Economic Revolution": Can It Solve Bread and Butter Questions?' 20 March, http://addisstandard.com/commentary-protest-driven-economicrevolution-can-solve-bread-butter-questions/ (accessed 5 June 2018)

AfDB (2016) Fobs for Youth in Africa: Strategy for Creating 25 Million Fobs and Equipping 50 Million Youth 2016-2025, African Development Bank, www.afdb.org/fileadmin/uploads/afdb/Documents/ Boards-Documents/Bank_Group_Strategy_for_Jobs_for_Youth_in_ Africa_2016-2025_Rev_2.pdf (accessed 20 May 2018)

Africa Renewal (2017) 'Youth Unemployment: Lessons from Ethiopia', www.un.org/africarenewal/magazine/may-2013/youthunemployment-lessons-ethiopia (accessed 2 May 2018)

Africa Renewal (2013) Touth Unemployment: Lessons from Ethiopia, www.un.org/africarenewal/magazine/may-2013/youthunemployment-lessons-ethiopia (accessed 17 June 2018)

Aring, M. (2012) Youth and Skills: Putting Education to Work, background paper prepared for the Education for All Global Monitoring Report 2012, http://unesdoc.unesco.org/images/0021/002178/217874e.pdf (accessed 13 November 2018)

Ayele, S.; Khan, S. and Sumberg, J. (2017) 'Introduction: New Perspectives on Africa's Youth Employment Challenge', IDS Bulletin 48.3: 1-12, http://bulletin.ids.ac.uk/idsbo/article/view/2866 (accessed 3 August 2018)

BBC (2018) Why has Ethiopia Imposed a State of Emergency?, 21 February, www.bbc.co.uk/news/world-africa-43113770 (accessed 25 June 2018)

BDU (forthcoming, 2018) 'Graduate Tracer Study on 2015 and 2016 Graduates of Bahir Dar Institute of Technology', Bahir Dar, Ethiopia: Bahir Dar University

CSA (2014) Statistical Report on the 2013 National Labour Force Survey, Addis Ababa: Central Statistical Agency, https://searchworks.stanford.edu/ view/11682466 (accessed 5 October 2018)

C.SA (2013) Education Statistics Annual Abstract, Addis Ababa: Central Statistical Agency, www.moe.gov.et (accessed 10 March 2018)

EEA (2008) Report on the Ethiopian Economy Volume VI 2006/7: The Current State of the Construction Industry, Addis Ababa, Ethiopia: Ethiopian Economic Association

FDRE (2016) Growth and Transformation Plan II (GTP II), Addis Ababa, Ethiopia: National Planning Commission, Federal Democratic Republic of Ethiopia, https://dagethiopia.org/new/images/ DAG_DOCS/GTP2_English_Translation_Final_June_21_2016.pdf (accessed 5 October 2018)

FDRE (2004) National Youth Policy, Addis Ababa, Ethiopia: Ministry of Youth, Sports and Culture, Federal Democratic Republic of Ethiopia, www.youthpolicy.org/national/Ethiopia_2004_National_ Youth_Policy.pdf (accessed 5 October 2018)

FDRE/Ministry of Education (2017) Education Statistics Annual Abstract, Addis Ababa, Ethiopia: Federal Democratic Republic of Ethiopia, www.moe.gov.et (accessed 10 March 2018) 
Gebremariam, E.B. (2017) 'The Politics of Youth Employment and Policy Processes in Ethiopia', IDS Bulletin 48.3: 33-50, http://bulletin.ids.ac.uk/idsbo/article/view/2868 (accessed 3 August 2018)

Gebru, B. (2017) 'The Problem of Youth Unemployment in Ethiopia', Ethiopian News, 1 December, www.ethiopiaprosperous.com/2017/12/ problem-youth-unemployment-ethiopia/ (accessed 17 May 2018)

Kilimani, N. (2017) 'Youth Employment in Developing Economies: Evidence on Policies and Interventions', IDS Bulletin 48.3: 13-32, http://bulletin.ids.ac.uk/idsbo/article/view/2867 (accessed 7 August 2018)

Korpela, K. (2017) 'Wishing for Better Jobs: Understanding the Mismatch between Education and Youth Employment in Ethiopia', MA thesis in Economic Development, School of Economics and Management, Lund University, http://lup.lub.lu.se/luur/ download?func $=$ downloadFile\&recordOId $=8925631 \&$ fileOId $=8925632$ (accessed 5 October 2018)

McGuinness, S.; Pouliakas, K. and Redmond, P. (2017) How Useful is the Concept of Skills Mismatch? Geneva: International Labour Organization, www.ilo.org/wcmsp5/groups/public/---ed_emp/---ifp_skills/ documents/publication/wcms_552798.pdf (accessed 3 May 2018)

Melese, M.K. (2012) Employment Challenges in Eastern Africa in the Context of Ethiopia, Nairobi: Friedrich Ebert-Stiftung

Mncayi, P. (2016) 'An Analysis of the Perceptions of Graduate Unemployment among Graduates from a South African University', International Journal of Social Sciences and Humanity Studies 8.1: 67-83

Salmi, J.; Sursock, A. and Olefir, A. (2017) Improving the Performance of Ethiopian Universities in Science and Technology. A Policy Note, Washington DC: World Bank

Sodipe, O.A. and Ogunrinola, O.I. (2011) 'Employment and Economic Growth Nexus in Nigeria', International Fournal of Business and Social Science 2.11: 232-9

Tefera, H. (2013) 'Management Control of Projects in Construction Industry: Ethiopian Context', unpublished MBA thesis, Business Administration, Indira Ghandi National Open University, http://repository.smuc.edu.et/bitstream/123456789/1538/1/ Hailemeskel\%20Tefera.pdf (accessed 10 October 2018)

Tran, T.T. (2014) Graduate Employability in Vietnam: A Loose Relationship between Higher Education and Employment Market, Hamburg: Anchor Academic Publishing

UNGTAD (2017) World Investment Report 2017: Investment and the Digital Economy, Geneva: United Nations, www.unctad.org/en/pages/PublicationWebflyer.aspx?publicationid=1782 (accessed 17 May 2018)

UNESCO (2012) Youth and Skills: Putting Education to Work, Paris: United Nations Educational, Scientific and Cultural Organization World Bank (2018) Africa's Pulse: Africa's Economic Future, Vol. 17, Washington DC: World Bank, https://openknowledge.worldbank.org/ handle/10986/29667 (accessed 5 October 2018) 
World Economic Forum (2014) Matching Skills and Labor Market Needs: Building Social Partnerships for Better Skills and Better fobs, Davos-Klosters: World Economic Forum

Yizengaw, J. (2016) 'Higher Education and Labor Market in Ethiopia: A Tracer Study of Graduate Employment in Engineering from Addis Ababa and Bahir Dar Universities', PhD thesis, International and Comparative Education, Addis Ababa University, http://etd.aau.edu.et/bitstream/handle/123456789/3799/ Jerusalem $\% 20$ Yibetal.pdf? sequence $=1$ \&isAllowed $=y$ (accessed 5 October 2018) 
